\title{
Spor ve Fiziksel Etkinlik İşletmelerinde İş Yaşam Kalitesinin Çalışanların İşten Ayrılma Niyetine Etkisi
}

\author{
The Effect of Quality of Work Life on Employee Turnover Intention in Sports and Physical \\ Activity Organizations
}

Süleyman Murat YILDIZ1

\section{ÖZET}

Çalışanların işten ayrılma niyeti üzerine birçok faktör etki etmekte ve iş yaşam kalitesi de bu faktörlerden birini oluşturmaktadır. Bu araştırmada, iş yaşam kalitesinin çalışanların işten ayrılma niyetine etkisi spor ve fiziksel etkinlik sektöründe incelenmiştir. Chen ve Farh (2000) tarafından geliştirilen iş yaşam kalitesi ölçeği ile Landau ve Hammer (1986) tarafından geliştirilen işten ayrılma niyeti ölçeğinin kullanıldığı bu araştırmada veriler ticari olarak faaliyet gösteren yüzme ve fitness işletmelerinde çalışan antrenörlerden $(\mathrm{N}=105)$ elde edilmiştir. Araştırma bulguları, iş yaşam kalitesinin işten ayrılma niyetin anlamlı ve negatif olarak etkilediğini göstermiştir. Bu sonuca göre, başarılı çalışanlarla istikrarlı bir hizmet sunmak isteyen spor ve fiziksel etkinlik işletmelerinin iş yaşam kalitesini artırarak çalışanlarının işten ayrılma niyetlerini azaltması akılcı bir yol olarak görülmektedir.

Anahtar Kelimeler: Iş yaşam kalitesi, ișten ayrılma niyeti, antrenör, spor ve fiziksel etkinlik sektörü.

\section{GíRiş}

İş yaşamı kalitesi ve işten ayrılma niyeti olguları son zamanlarda araştırmalara daha fazla konu olmaya başlamıştır. Bu olgulara artan ilginin temelinde, gittikçe artan rekabetten dolayı, özellikle hizmet sektörlerindeki insan kaynaklarının daha da önemli hale gelmesi yatmaktadır (Altarawneh ve Al-Kilani, 2010). Hizmet sektörlerinde hizmetin ana unsurunun insan olması ve hizmet kalitesinin insanlar (çalışanlar) tarafından belirlenmesi göz önüne alındığında, insan kaynaklarının spor ve fiziksel etkinlik sektörü için de oldukça önemli bir konu olduğu açıktır. Bir işletmede yer alan çalışanlar, kendilerine sunulan olanaklar, yönetim ile ilişkiler, fiziki ve sosyal ortam, prosedürel yapı ve benzeri durumlardan etkilenmektedirler ( $\mathrm{Hu}$ ang, Lawyer ve Lei, 2007). Çalışanların fiziksel ve psikolojik ihtiyaçlarını karşılayan spor ve fiziksel etkinlik işletmeleri çalışanlarını uzun süre ellerinde tutarlar, karşılayamayanlar ise çalışanlarını kaybederler (Yıl-

\begin{abstract}
Quality of work life is one of the many factors that influence employees' turnover intention. In this study, the effect of quality of work life on turnover intention in sports and physical activity organizations was investigated. The quality of work life scale developed by Chen and Farh (2000) was used to measure quality of work life and turnover intention scale developed Landa uand Hammer (1986) was used to measure employees' turnover intention. The data were obtained from the trainers $(N=105)$ of swimming and fitness clubs. The results of the study demonstrated that quality of work life significantly and inversely influenced turnover intention of trainers. According to these results, sports and physical activity organizations that seek to provide attractive work conditions to the successful employees should try to implement programs to improve the quality of work life in their organizations to reduce the intentions of employee turnover.
\end{abstract}

Keywords: Quality of work life, turnover intention, trainer, sports and physical activity sector.

dız, 2011). Bu açıdan bakıldığında, iş yaşamı kalitesi ile işten ayrılma niyeti olguları spor ve fiziksel etkinlik işletmeleri açısından önem kazanmaktadır. İş yaşamı kalitesi, işyerindeki çalışanın lehine olan (fiziki ve psikolojik ihtiyaçlarını karşılamaya yönelik) tüm durumları ifade ederken, işten ayrılma niyeti ise çalışanın gönüllü olarak işletmeden ayrılma durumunu ifade eder. Uzun süre çalışanlara sahip olan spor ve fiziksel etkinlik işletmeleri istikrarlı bir hizmet üretimine sahip olurken, personel devir oranı yüksek olanlar ise hizmet kesintisine ve diğer olumsuzluklara katlanmak zorunda kalırlar (Smith, Daskalaki, Elger ve Brown, 2004).

İşten ayrılma, her tip organizasyonda görülen yaygın bir sorundur (Yin-Fah, Foon, Chee-Leong ve Osman, 2010) ve bu sorun hizmet sektöründe daha fazladır (Wasmuth ve Davis, 1993). Örneğin 1983 yılında Kuzey Amerika'da 20 otel üzerinde yapılan bir araştırmada gönüllü olarak işten ayrılma oranı \%60 
olarak görülmüştür (Wasmuth ve Davis, 1983). Eylül 2005-Ağustos 2006 arasındaki verilere göre, Birleşik Devletlerdeki serbest zaman ve konaklama sektöründeki gönüllü olarak işten ayrılma oranı \%52,2'dir (www.wf1broward.com). Bu oranlardan da görüleceği üzere, hizmet sektöründeki işten ayrılma niyeti oldukça yüksektir. Dolayısıyla, hizmet sektörü içerisinde yer alan spor ve fiziksel etkinlik işletmelerini de bu tip sorundan ayrı görmek mümkün değildir. Bu noktada, spor ve fiziksel etkinlik işletmelerinde işten ayrılma niyeti üzerinde etkili olabilecek olgular önem kazanmaktadır. Buradan hareketle, bu araştırmada iş yaşam kalitesinin işten ayrılma niyetine olan etkisinin incelenmesi amaçlanmıştır.

\section{LITERATÜR BILGI}

\section{1. İş Yaşam Kalitesi}

İş yaşamı kalitesi ilk olarak 1960'larda ortaya çıkmış (Davis, 1977) ve 1972 yılında Uluslararası Çalışma Illişkileri Konferansı (International Labor Relations Conference) sırasında gündeme gelmiştir (Moen, 1999). İş yaşamı kalitesi kavramının orijinal kullanımı işçi ve iş ortamı arasındaki ilişkinin kalitesi üzerine olmuş; işin teknik ve ekonomik boyutunun yanında, göz ardı edilen insan boyutunun vurgulanması amaçlanmıştır (Al-Qutop ve Harrim, 2011). Bu çerçevede, yöneticiler tarafından, işin insancıllaştırılması (Cherns, 1975), yani çalışanların karar süreçlerine katılımı ile demokrasi ortamının oluşturulması (Kornbluh, 1984), çalışanların fiziksel, psikolojik ve sosyal ihtiyaçlarının iyileştirilmesi olarak ele alınmıştır (Beh ve Rose, 2007).

İş yaşamı kalitesinin tanımı ve yapısının tam olarak ne olduğu ile ilgili olarak araştırmacılar arasında tam bir fikir birliği bulunmamaktadır (Al-Qutop ve Harrim, 2011). Robbins (1998) iş yaşamı kalitesini "bir organizasyonda -çalışma hayatının dizaynına yönelik kararları alma ve paylaşımına imkan veren mekanizmalar ile- çalışanların ihtiyaçlarına yanıt veren bir süreç" olarak tanımlamaktadır (Xhakollari, 2011). Lau (2000) ise iş yaşamı kalitesini "iş yeri ortamında; ödülleri, iş güvenliği ve gelişme fırsatları sağlayarak çalışanların memnuniyetini destekleyen ve teşvik eden elverişli koşulların oluşturulması" şeklinde tanımlamaktadır. İş yaşamı kalitesinin yapısı değişik şekillerde ortaya konulmaktadır (Edvardsson ve Gustavsson, 2003; Nadler ve Lawler, 1983). Değiş̧ik şekilde ortaya konsa da, bu yapılar, çalışanların fiziki ve psikolojik ihtiyaçlarını karşılamaya yönelik olarak iş yaşamını doğrudan veya dolaylı olarak etkileyen, iş ortamı-çaIışan uyumunu sağlayan tüm unsurları içermektedir (Demirbilek ve Türkan, 2008). Bu unsurların çalışan- ların ve işletmelerin performansı ve başarısının ana unsurları olduğu yönünde bir fikir birliği bulunmaktadır (Al-Qutop ve Harrim, 2011). Ayrıca, iş yaşamı kalitesinin çoklu yapısının evrensel ve daimi bir özellik taşımayabileceği de ifade edilmektedir (Lau ve May, 1998). Literatürde yer alan iş yaşamı kalitesi ile ilgili anahtar kavramlardan bazıları şunlardır: adil ücret, güvenli iş koşulları, yeni beceri öğrenme ve kullanma olanakları, kariyer gelişim olanakları, bireysel hakların korunması ve iş ile övünme (Schermerhorn, Hunt ve Osborn, 1994).

İşletmelerin içinde bulundukları rekabet ortamında müşteri tatminini sağlamak ve sadık müşteriler oluşturmak için yüksek miktarlarda paralar harcadıkları ileri sürülmektedir (Demir, 2011). Diğer taraftan, müşteri tatmininin sağlanmasında en etkili unsurlardan birisinin öncelikle çalışanların tatmininin oluşturulmasının gerekliliği de ifade edilmektedir (Yıldız, 2011). Bu açıdan bakıldığında, işletmelerin hedefledikleri başarıya ulaşmasında en önemli araçlardan birisinin çalışanlar olduğu ve dolayısıyla çalışma ortamını iyileştiren iş yaşam kalitesinin modern yönetim anlayışı içerisinde yer alması gerekliliği açık bir şekilde görülmektedir.

\section{2. Çalışanların İşten Ayrılma Niyeti}

İşten ayrılma niyeti, çalışanın işletmede kalma ile ilgili kararının yansımasıdır (Altarawneh ve Al-Kilani, 2010) ve "çalışanın bir iş yerindeki işini bırakma ile ilgili niyeti" olarak tanımlanmaktadır (Nazim, 2008). İşten ayrılma, "gönüllü/isteyerek ayrılma" ve "gönülsüz/istemeyerek ayrılma" olarak iki şekilde kategorize edilmektedir (Watrous, Huffman ve Pritchard, 2006). Gönüllü ayrılma, işletmeden ayrılmada bireysel olarak bir karar almayı ifade eder (Wells ve Peachey, 2011). Gönüllü ayrılmanın ana sebepleri organizasyonel faktörler (ücret, terfi, yönetici ile ilişkiler, daha iyi iş fırsatı vb.) ya da bireysel faktörlerdir (sağlık, emeklilik, tayin vb. gibi). Gönülsüz ayrılma ise, işten çıkarılma ya da atılma anlamına gelmektedir (Chang ve Chang, 2008). Bu durum zayıf performans ya da uygun olmayan davranıştan dolayı meydana gelmektedir (www.wf1 broward.com).

Çalışanın ayrılmasının işletmelere direkt ve endirekt maliyetleri bulunmaktadır. Yeni bir personelin bulunması, işe alınması ve eğitimi gibi faaliyetler direkt maliyetleri içerirken; geride kalan çalışanların moralinin azalması, iş yükünün artması ve sosyal sermaye kaybı endirekt maliyetleri içermektedir (Staw, 1980; Dess ve Shaw 2001). Sonuç olarak, gerek iyi çalışanın işten ayrılmasıyla yaşanan insan kaynağı kaybı, gerekse devam eden iş akışını bölmesi açısın- 
dan işten ayrılma niyeti organizasyonları olumsuz yönde etkilemektedir (Şahin, 2011). Dolayısıyla, işletmelerin çalışanların işten ayrılma niyetlerini ortadan kaldırmalarına yönelik çabaları istikrarlı bir hizmet sunumu açısından önemli bir konu olarak karşımıza çıkmaktadır. Bu bağlamda, bir taraftan çalışanların motivasyonunu ve iş tatminini yükselmenin (Wells ve Peachey, 2011); diğer taraftan rol belirsizliğini ve rol çatışmasını ortadan kaldırmanın işten ayrılma niyetinin azaltılmasında etkili unsurlar olduğu ifade edilmektedir (Gormley ve Kennerly, 2010; Lambert ve Paoline, 2010).

\section{3. İş Yaşam Kalitesi ve Çalışanların İşten Ayrılma Niyeti İlişkisi}

İş yaşamı kalitesi ve işten ayrılma niyeti ayrı ayrı olarak son zamanlarda araştırmalara daha fazla konu olsa da iki değişken arasındaki ilişkileri inceleyen araştırmalar oldukça sınırlıdır. Muhasebe firmalarındaki çalışanlar (Huang, Lawyer ve Lei, 2007), devlet üniversitesinde görev yapan akademisyenler (Turunç, Tabak, Şeşen ve Türkyılmaz, 2010) ve bilgi teknoloji firmasında çalışanlar (Korunka, Hoonakker ve Carayon, 2008) üzerinde yapılan araştırmalarda iş yaşam kalitesi ve işten ayrılma niyeti arasında negatif ve anlamlı ilişkiler görülmüştür. Diğer hizmet sektörlerinde görülen bu iki değişken arasındaki ilişkinin düzeyi, spor ve fiziksel etkinlik sektöründe faaliyet gösteren işletmelerde bulunan çalışanlar üzerinde herhangi bir araştırma olmadığından dolayı bilinmemektedir. Buradan hareketle, spor ve fiziksel etkinlik sektöründe bulunan çalışanlar bağlamında iş yaşamı kalitesi ve alt boyutları ile işten ayrılma niyeti değişkenleri arasındaki ilişkinin ortaya konulabilmesi amacıyla aşağıdaki hipotezler geliştirilmiştir.

$\mathrm{H}_{1}$ : "İ̧̧ yaşamı kalitesi" ile antrenörlerin işten ayrılma niyeti arasında negatif ve anlamlı ilişki vardır.

$\mathrm{H}_{2}$ : "Iş̧ yaşam dengesi" ile antrenörlerin işten ayrılma niyeti arasında negatif ve anlamlı ilişki vardır.

$\mathrm{H}_{3}$ : "Işin özellikleri" ile antrenörlerin işten ayrılma niyeti arasında negatif ve anlamlı ilişki vardır.

$\mathrm{H}_{4}$ : "Yönetimsel davranışlar" ile antrenörlerin işten ayrılma niyeti arasında negatif ve anlamlı ilişki vardır.

$\mathrm{H}_{5}$ : "Ödül \& yarar" ile antrenörlerin işten ayrılma niyeti arasında negatif ve anlamlı ilişki vardır.

\section{YÖNTEM}

Bu araştırmada ölçme aracı olarak Chen ve Farh (2000) tarafından geliştirilen iş yaşam kalitesi ölçeği (Huang vd.,2007) ile Landau ve Hammer (1986) tarafından geliştirilen işten ayrılma niyeti ölçeği kullanıl- mıştır. Orijinal ölçekler önce Türkçe'ye çevrilmiş, sonra 2 alan uzmanına ve 9 antrenöre incelettirilmiştir. Küçük düzeltmeler yapıldıktan sonra ölçekler uygulama formu haline getirilmiştir. Her iki ölçekteki ifadeler ("1=Hiç katılmıyorum", "2=Katılmıyorum", "3=Kararsızım", "4=Katılıyorum", "5=Tamamen katılıyorum"dan oluşan) Likert tipi 5'li derece ile ölçülmüştür.

Ölçek formları ticari olarak faaliyet gösteren yüzme ve fitness işletmelerindeki antrenörlere elektronik posta ile gönderilmiş ve tekrar elektronik posta ile alınmıştır. Yüzme ve fitness antrenörlerin tespiti ve iletişiminde internet ortamındaki bir sosyal paylaşım sitesi ile işletmelerin web sitesinden yararlanılmıştır. Araştırmaya katılım hususunda olumlu yanıt alınan antrenörlere 191 form iletilmiş, ancak bunların 135'i geri dönmüştür. Yapılan incelemede eksik ve hatalı olan 20 form analizlere dahil edilmemiş, sonuç olarak tam olarak dolduruldukları görülen 105 ölçek formu analiz için uygun bulunmuştur.

\section{BULGULAR}

\subsection{Demografik Özellikler}

Araştırmaya katılanların ( $\mathrm{N}=105) \% 55,2$ 'si fitness, $\% 44,8^{\prime} i$ ise yüzme antrenörüdür. Yarıdan fazlasını erkeklerin oluşturduğu antrenörlerin \%81'i bekardır. Ayrıca, \%79'u antrenör, \%21'i ise baş antrenör olan katılımcıların \%94,3'ü üniversite eğitimine sahiptir ve \%80'i 21-30 yaş aralığında bulunmaktadır (Tablo 1).

Tablo 1: Demografik Özelliklere Yönelik Analiz Sonuçları

\begin{tabular}{|l|l|c|c|}
\hline \multirow{2}{*}{ Değişkenler } & & Frekans & $\begin{array}{c}\text { Yüzde } \\
(\%)\end{array}$ \\
\hline \multirow{2}{*}{ Cinsiyet } & Erkek & 59 & 56,2 \\
\cline { 2 - 4 } & Kadın & 46 & 43,8 \\
\hline \multirow{3}{*}{ Medeni Durum } & Evli & 20 & 19 \\
\cline { 2 - 4 } & Bekar & 85 & 81 \\
\hline \multirow{4}{*}{ Yaş } & 20 ve altı & 4 & 3,8 \\
\cline { 2 - 4 } & $21-30$ & 84 & 80 \\
\cline { 2 - 4 } & $31-40$ & 14 & 13,3 \\
\cline { 2 - 4 } & 41 ve üstü & 3 & 2,9 \\
\hline \multirow{2}{*}{ Eğitim Durumu } & Lise & 6 & 5,7 \\
\cline { 2 - 4 } & Üniversite & 99 & 94,3 \\
\hline \multirow{5}{*}{ Galışma Süresi } & 5 yıl ve altı & 91 & 86,7 \\
\cline { 2 - 4 } & $6-10$ yıl & 11 & 10,5 \\
\cline { 2 - 4 } & $11-15$ yıl & 2 & 1,9 \\
\cline { 2 - 4 } & $16-20$ yıl & 1 & 1 \\
\hline \multirow{2}{*}{ Branşlar } & Antrenör & 83 & 79 \\
\cline { 2 - 4 } & Baş Antrenör & 22 & 21 \\
\hline & Yüzme & 47 & 44,8 \\
\cline { 2 - 4 } & Fitness & 58 & 55,2 \\
\hline
\end{tabular}

\subsection{Geçerlik ve Güvenirlik Analizleri}

Araştırmanın hipotez testlerine geçmeden önce, ölçeklere bir takım testlerin yapılması gerekli görül- 
müştür. Kolmogorov-Smirnov testi sonucuna göre iş yaşam kalitesi ölçeğinin değeri $0,946(p>0,05)$, işten ayrılma niyeti ölçeğinin değeri ise 0,098 'dir $(p>0,05)$. Bu değerler her iki ölçeğin normal dağılım sergilediğini göstermektedir. İş yaşam kalitesinin KMO değeri 0,838 olup bu değer "çok iyi" düzeyi yansıtmaktadır. İşten ayrılma niyeti ölçeğinin KMO değeri 0,718'dir ve bu değer ise "iyi" düzeyi yansıtmaktadır. Tüm ölçeklerin Bartlett's Sphericity testi sonucu da anlamlıdır $(p<0,001)$. Tüm bu sonuçlar faktör analizinin uygulanabilirliğini göstermektedir.

Ölçeklerin yapı geçerliliği için Temel Bileşenler Analizi ve Varimax Döndürme teknikleri kullanılmıştır. Analiz sonucuna göre, iş yaşam kalitesi ölçeğinin özdeğeri 1'den büyük dört bileşenli bir yapısı ortaya çıkmıştır. Bunlar; iş/yaşam dengesi, işin özellikleri, yönetimsel davranışlar ve ödül \& yarar boyutlarıdır. Faktör yükleri 0,620 ile 0,877 arasında değişen boyutların Alpha iç tutarlılık katsayıları ise 0,734 ile 0,849 arasındadır (Tablo 2). Aynı analizlerin kullanıldığı işten ayrılma niyeti ölçeği tek boyutlu olup, maddelerin faktör yükleri 0,873 ile 0,943 arasında değişmektedir. Alpha iç tutarlılık katsayısı ise 0,896'dır (Tablo 3). Ayrıca, ölçeklerin güvenirliğinin belirlenmesinde tamamlayıcı ölçüm olan Açıklanan Ortalama Varyans (AVE) değerleri kabul edilebilir alt sınır olan 0,50'nin üzerindedir. Tüm bu sonuçlar her iki ölçeğin geçerli ve güvenilir olduğunu, bununla birlikte orijinal ölçeklerle de tutarlı olduğunu göstermektedir.

Tablo 2: İ̧ Yaşam Ölçeğinin Faktör Analizi Sonuçları

\begin{tabular}{|c|c|c|c|c|c|c|}
\hline Maddeler & M & SD & F1 & F2 & F3 & F4 \\
\hline $\begin{array}{l}\text { İşyerimin dışındaki diğer işyerlerindeki benzer işlerle kendimi } \\
\text { karşılaştırdığımda daha fazla ödüllendirildiğimi düşünüyorum. }\end{array}$ & 3,07 & 1,26 & 864 & & & \\
\hline $\begin{array}{l}\text { İşyerimdeki benzer diğer işlerle kendimi karşılaştırdığımda daha fazla } \\
\text { ödüllendirildiğimi düşünüyorum. }\end{array}$ & 2,98 & 1,23 & 809 & & & \\
\hline Bu işyeri benim refahımı önemser. & 3,36 & 1,18 & ,725 & & & \\
\hline Şu anki işimin mesai süresi makuldür. & 3,67 & 1,28 & & 872 & & \\
\hline Şu anki işim aile yaşamını etkilemez. & 3,63 & 1,35 & & ,845 & & \\
\hline Şu anki işyüküm makul düzeydedir. & 3,79 & 1,17 & & ,701 & & \\
\hline Amirim bana işimi nasıl yapacağımı/geliştireceğimi söyler. & 3,62 & 1,12 & & & 877 & \\
\hline Amirim işim ile ilgili problemleri çözmek için bana yardımcı olur. & 3,90 & 1,11 & & & ,770 & \\
\hline Amirim işimde iyi bir performans gösterdiğim zaman beni takdir eder. & 3,71 & 1,20 & & & ,669 & \\
\hline Şu anki işim benim için yaratıcı ve anlamlıdır. & 3,97 & 0,96 & & & & 819 \\
\hline Şu anki işim ulaşılması zor bir iş ve bu iş beni motive ediyor. & 3,48 & 1,13 & & & & 810 \\
\hline İşimi nasıl yapacağım ile ilgili kendim karar veririm. & 3,75 & 1,20 & & & & 620 \\
\hline \multicolumn{3}{|c|}{ Percentage of Variance Explaned } & 45,396 & 11,785 & 10,492 & 8,458 \\
\hline \multicolumn{3}{|c|}{ Cumulative $\%$ of Variance Explaned } & 45,396 & 57,181 & 67,673 & 76,131 \\
\hline \multicolumn{3}{|c|}{ Cronbach Alpha } & 0,839 & 0,835 & 0,849 & 0,734 \\
\hline & & AVE & 0,64 & 0,66 & 0,60 & 0,57 \\
\hline
\end{tabular}

( Not: F1=Ödül\&Yarar, F2=Iş/Yaşam Dengesi, F3=Yönetimsel Davranışlar, F4=Işin Özellikleri)

Tablo 3: İşten Ayrılma Niyeti Ölçeğinin Faktör Analizi Sonuçları

\begin{tabular}{|l|c|c|c|}
\hline Maddeler & M & SD & F1 \\
\hline Bu işi bırakmayı ciddi bir şekilde düşünüyorum. & 2,24 & 1,16 &, 943 \\
\hline Şu anda kendime dışarıda bir iş arıyorum. & 2,16 & 1,26 &, 923 \\
\hline Daha iyi bir iş bulduğum taktirde bu işi bırakacağım. & 3,03 & 1,36 &, 873 \\
\hline \multicolumn{2}{|r|}{ Percentage of Variance Explaned } & 83,466 \\
\hline \multicolumn{2}{|r|}{ Cronbach Alpha } & 0,896 \\
\hline \multicolumn{2}{|r|}{ AVE } & 0,83 \\
\hline
\end{tabular}

( Not: F1=iş̧ten Ayrılma Niyeti)

\subsection{Bağımsız Örneklem $\mathbf{t}$ Testi}

Değişkenler arasındaki ilişkiyi araştırmada yer alan tüm antrenörlere genelleyebilmek için yüzme ve fitness antrenörleri iki ayrı grup olarak ele alınmış ve bu gruplara bağımsız örneklem $t$ testi uygulanmıştır. Test sonuçlarına göre, tüm maddelerde herhangi bir anlamlılık söz konusu değildir $(p>0,05)$. Dolayısıyla bu sonuçlar, değişkenler arasındaki ilişkilerin bu çalış- madaki tüm antrenörlere genellenebileceğini göstermektedir (Tablo 4).

\subsection{Korelasyon Analizi}

Korelasyon analizi sonuçlarına göre, işten ayrılma niyeti iş yaşam kalitesi ile anlaml, negatif ve kuvvetli bir ilişkiye sahiptir $(r=-0,650 ; p<0,01)$. Isşten ayrılma niyeti, aynı zamanda, iş yaşam kalitesinin tüm boyutları ile de anlamlı ve negatif bir ilişkiye sahiptir ve bu 
Tablo 4: Gruplar Arası Bağımsız Örneklem t Testi Sonuçları

\begin{tabular}{|c|c|c|c|c|c|}
\hline Değisskenler & Gruplar & $M$ & SD & $t$ & $p$ \\
\hline \multirow{2}{*}{$\begin{array}{l}\text { İş/Yaşam } \\
\text { Dengesi }\end{array}$} & Yüzme & 3,61 & 1,25 & \multirow[b]{2}{*}{,- 927} & \multirow{2}{*}{,356 } \\
\hline & Fitness & 3,80 & 0,87 & & \\
\hline \multirow{2}{*}{ İşin Özellikleri } & Yüzme & 3,65 & 0,98 & \multirow{2}{*}{$-1,061$} & \multirow{2}{*}{ 291 } \\
\hline & Fitness & 3,83 & 0,77 & & \\
\hline \multirow{2}{*}{$\begin{array}{l}\text { Yönetimsel } \\
\text { Davranışlar }\end{array}$} & Yüzme & 3,70 & 1,13 & \multirow{2}{*}{,- 491} & \multirow{2}{*}{ 624 } \\
\hline & Fitness & 3,80 & 0,83 & & \\
\hline \multirow{2}{*}{ Ödül \& Yarar } & Yüzme & 3,12 & 1,19 & \multirow{2}{*}{-145 } & \multirow{2}{*}{ 885 } \\
\hline & Fitness & 3,15 & 0,90 & & \\
\hline \multirow{2}{*}{$\begin{array}{l}\text { Isten Ayrılma } \\
\text { Niyeti }\end{array}$} & Yüzme & 2,44 & 1,09 & \multirow{2}{*}{,- 388} & \multirow{2}{*}{ 699 } \\
\hline & Fitness & 2,53 & 1,23 & & \\
\hline
\end{tabular}

Tablo 5: Değişkenler Arası Korelasyon Sonuçları

\begin{tabular}{|l|c|c|c|c|c|c|c|c|}
\hline Değişkenler & $\mathrm{M}$ & $\mathrm{SD}$ & 1 & 2 & 3 & 4 & 5 & 6 \\
\hline 1.Cinsiyet & - & - & 1 & & & & & \\
\hline 2.Medeni Durum & - & - &, 184 & 1 & & & & \\
\hline 3.Yaş & - & - &,$- 338^{* *}$ &,$- 424^{* *}$ & 1 & & & \\
\hline 4.Eğitim Durumu & - & - &,- 113 &, 090 &,- 087 & 1 & & \\
\hline 5.Görev & - & - &,- 061 &,- 051 &, 031 &,- 026 & 1 & \\
\hline 6.Çalışma Süresi & - & - &,$- 193^{*}$ &,$- 327^{* *}$ &, 048 &,- 082 &, 076 & 1 \\
\hline 7.Statü & - & - &,- 030 &,- 108 &, $258^{* *}$ &,- 075 &,- 134 &, 059 \\
\hline 8.İş/Yaşam Dengesi & 3,70 & 1,10 &,- 016 &,$- 206^{*}$ &, 007 &,- 030 &, 088 &, 167 \\
\hline 9.İşin Özellikleri & 3,73 & 0,89 &,- 155 &,- 144 &, 178 &,- 057 &, 101 &, 141 \\
\hline 10.Yönetimsel Davranışlar & 3,74 & 1,00 &,- 136 &,- 057 &, 043 &,- 034 &, 047 &, 075 \\
\hline 11.Ödül \& Yarar & 3,13 & 1,06 &,- 086 &, 140 &, 101 &,- 071 &, 014 &,- 065 \\
\hline 12. İş Yaşam Kalitesi & 3,58 & 0,79 &,- 122 &,- 083 &, 100 &,- 061 &, 078 &, 100 \\
\hline 13. Iş̧ten Ayrılma Niyeti & 2,48 & 1,15 &, 075 &, $211^{*}$ &,- 071 &, 175 &, 039 &,$- 193^{*}$ \\
\hline
\end{tabular}

( Not: ${ }^{*} p<0,05,{ }^{* *} p<0,01$ )

Tablo 5: Değişkenler Arası Korelasyon Sonuçları (Devam)

\begin{tabular}{|l|c|c|c|c|c|c|c|c|}
\hline Değişkenler & M & SD & 7 & 8 & 9 & 10 & 11 & 12 \\
\hline 1.Cinsiyet & - & - & & & & & & \\
\hline 2.Medeni Durum & - & - & & & & & & \\
\hline 3.Yaş & - & - & & & & & & \\
\hline 4.Eğitim Durumu & - & - & & & & & & \\
\hline 5.Görev & - & - & & & & & & \\
\hline 6.Çalışma Süresi & - & - & & & & & & \\
\hline 7.Statü & - & - & 1 & & & & & \\
\hline 8.İ̧̧/Yaşam Dengesi & 3,70 & 1,10 &,- 123 & 1 & & & & \\
\hline 9.Işin Özellikleri & 3,73 & 0,89 &,- 032 &, $475^{* *}$ & 1 & & & \\
\hline 10.Yönetimsel Davranışlar & 3,74 & 1,00 &,- 136 &, $474^{* *}$ &, $407^{* *}$ & 1 & & \\
\hline 11.Ödül \& Yarar & 3,13 & 1,06 &,- 046 &, $424^{* *}$ &, $511^{* *}$ &, $576^{* *}$ & 1 & \\
\hline 12. İş Yaşam Kalitesi & 3,58 & 0,79 &,- 110 &, $773^{* *}$ &, $747^{* *}$ &, $789^{* *}$ &, $809^{* * *}$ & 1 \\
\hline 13. İşten Ayrıma Niyeti & 2,48 & 1,15 &,- 006 &,$- 572^{* *}$ &,$- 414^{* *}$ &,$- 536^{* *}$ &,$- 493^{* *}$ &,$- 650^{* * *}$ \\
\hline
\end{tabular}

( Not: ${ }^{*} p<0,05,{ }^{* *} p<0,01$ )

boyutlar içerisinde en yüksek ilişki iş/yaşam dengesinde $(r=-0,572 ; p<0,01)$ görülmüştür. Bu sonuçlara göre bu araştırmada yer alan tüm hipotezler kabul edilmiştir (Tablo 5).

\subsection{Hiyerarşik Regresyon Analizi}

Bu aşamada, işten ayrılma niyetinin bağımlı değişken olduğu, kontrol değişkenleri ile iş yaşam kalitesinin bağımsız değişken olarak yer aldığı iki adımlı hiyerarşik regresyon analizi uygulanmıştır. Analiz sonucu, iş yaşam kalitesinin işten ayrılma niyetini anlamlı ve negatif etkilediğini $(\beta=-0,644 ; p<0,001)$, bununla birlikte 0,49 düzeyinde açıklama gücüne sahip olduğunu göstermektedir. Öte yandan, kontrol değişkenleri ile işten ayrılma niyeti arasında anlamlı bir sebep sonuç ilişkisi bulunamamıştır. Ayrıca, korelasyon analizinde görülen işten ayrılma niyetinin medeni durum ve çalışma süresi ile olan anlamlı ilişkisi hiyerarşik regresyon analizi ile ortadan kalktığı da görülmüştür (Tablo 6). 
Tablo 6: İşten Ayrılma Niyeti ile Bağımsız Değişkenler Arasındaki İlişkileri Belirlemeye Yönelik Hiyerarşik Regresyon Analizi Sonuçları

\begin{tabular}{|l|c|c|c|c|c|c|}
\hline \multirow{2}{*}{$\begin{array}{l}\text { Bağımsız } \\
\text { Değişkenler }\end{array}$} & \multicolumn{3}{|c|}{ Adım 1} & \multicolumn{3}{c|}{ Adım 2 } \\
\cline { 2 - 7 } & Beta & $\mathrm{t}$ & $\mathrm{p}$ & Beta & $\mathrm{t}$ & $\mathrm{P}$ \\
\hline 1.Cinsiyet &, 053 &, 495 &, 622 &, 000 &,- 003 &, 997 \\
\hline 2.Medeni Durum &, 164 & 1,440 &, 153 &, 157 & 1,828 &, 071 \\
\hline 3.Yaş &, 025 &, 212 &, 832 &, 086 &, 961 &, 339 \\
\hline 4.Eğitim Durumu &, 163 & 1,642 &, 104 &, 121 & 1,613 &, 110 \\
\hline 5.Görev &, 068 &, 692 &, 490 &, 096 & 1,292 &, 200 \\
\hline 6.Çalışma Süresi &,- 125 & $-1,182$ &, 240 &,- 076 &,- 950 &, 344 \\
\hline 7.Statü &, 036 &, 351 &, 726 &,- 055 &,- 711 &, 479 \\
\hline 8. İş Yaşam Kalitesi & - & - & - &,- 644 & $-8,579$ &, $000^{* *}$ \\
\hline F & \multicolumn{7}{|c|}{1,399} & & 11,340 &, 486 \\
\hline R &, 092 & & &, 443 & \\
\hline Adjustedr ${ }^{2}$ &, 026 &
\end{tabular}

( Not: Standardize edilmiş beta değerleri kullanılmıştır, ${ }^{* *} \mathrm{p}<0,001$ )

\section{TARTIŞMA VE SONUÇ}

Bu araştırma, iş yaşam kalitesinin çalışanların işten ayrılma niyeti ile ilişkili olduğunu göstermektedir. İş yaşam kalitesi işten ayrılma niyeti üzerinde anlamlı ve negatif etkilidir ve spor ve fiziksel etkinlik işletmelerinde çalışanların iş yaşam kalitesi artırılarak işten ayrılma niyetlerinin azaltılabileceği sonucunu ortaya koymaktadır. Bu sonuç, diğer hizmet sektörlerinde yapılan araştırmalar ile benzerlik göstermektedir. Örneğin, muhasebe firmalarındaki çalışanlar (Huang vd., 2007), devlet üniversitesinde görev yapan akademisyenler (Turunç vd., 2010) ve bilgi teknoloji firmasındaki çalışanlar (Korunka vd., 2008) üzerinde yapılan araştırmalarda iş yaşam kalitesi arttıkça işten ayrılma niyetinin anlamlı bir şekilde azaldığı görülmüştür.

Ayrıca, bu araştırmada, iş yaşam kalitesine ait tüm boyutlar işten ayrılma niyeti ile anlamlı ve negatif ilişsilidir. Bu boyutlardan iş/yaşam dengesi en yüksek ilişki düzeyine $(r=-0,572)$ sahiptir. Benzer şekilde, Huang vd. (2007) de iş/yaşam dengesi ile işten ayrılma niyetinin en yüksek ilişki düzeyine sahip olduğunu ( $r=-0,480)$ bulmuştur. Buna göre, iş yaşam dengesini iyi ayarlayamayan spor ve fiziksel etkinlik işletmelerinin çalışanlarını kaybetmeye daha yakın olacağı, dolayısıyla bu durumu göz önüne alarak yöneticilerin çalışanların iş/ yaşam dengesini ayarlamaları öncelikli bir konu olduğu söylenebilir. Bununla birlikte, çalışanla<ra yönelik pozitif davranışlar ile çalışanlara hak ettiği ödülün ve yararın sağlanması, yaratıcı ve anlamlı iş özelliklerinin oluşturulması, yöneticilerin üzerinde durması gereken diğer konular olarak görülmektedir.

Literatür, iş yaşam kalitesinin çalışanlar ve işletmeler üzerinde güçlü pozitif etkileri olduğunu göstermektedir. Bu etkiler, çalışanlarda devamsızlığın azalması (Demir, 2011; Havlovic, 1991), personel devir oranının ve şikayetlerin azalması; iş tatmininin
(Wallace, Pichler ve Hayes, 2007), örgütsel vatandaşlık davranışının (Al-Qutop ve Harrim, 2011), örgütsel bağlılığın (Erdem, 2010; Zin, 2004), üretkenliğin (Nayeri, Salehi ve Noghabi, 2011) ve performansın (Lau ve May, 1998; Lau, 2000; Sabarirajan ve Geethanjali, 2011) artması şeklindedir. Bu pozitif etkiler çalışanlara istikrarlı bir iş yaşamı, işletmelere ise kârlılık sunar. Diğer taraftan, işten ayrılma niyeti insan kaynakları ve işletme yönetimi bağlamında önemli bir problem olarak görülmektedir. İşten ayrılmanın fazla olması istihdam maliyetini artırdığı gibi, işletmenin bilgi sermayesini de azaltır (Liu, Liu ve Hu, 2010). Bu noktadan bakıldığında, spor ve fiziksel etkinlik işletmelerinde bu tür problemlerin yaşamaması için bazı yönetimsel çabaların gösterilmesine ihtiyaç bulunmaktadır. Bu çabalardan birisinin iş yaşam kalitesi olduğu açık bir şekilde görülmektedir. Bu bağlamda, bir taraftan çalışanlara iş ve iş dışındaki yaşamlarında denge kuracak şekilde çalışma süresi ve iş yükünün verilmesi, işle ilgili özerklik sağlanması, başarıya karşılık ödül verilmesi; diğer taraftan çalışanların fikirlerinden yararlanılması, problem çözme becerilerinin geliştirilmesi akılcı bir yol olarak görülmektedir. Böylece çalışanların işten ayrılma niyeti (ve buna bağlı olarak işe geç gelme, devamsızlık, verimsizlik, performans düşüklüğü vb. gibi durumlar) iyice zayıflayacaktır. Sonuçta spor ve fiziksel etkinlik işletmeleri istikrarlı çalışanlarla istikrarlı bir hizmete sahip olacaktır.

Bu araştırma spor ve fiziksel etkinlik sektöründe yer alan yüzme ve fitness alanları ile sınırlıdır. Gerek örneklem miktarından, gerekse spor ve fiziksel etkinlik sektörünün çok çeşitli faaliyet alanlarının bulunmasından dolayı, bu araştırmanın sonuçları tüm sektöre genellenemez. Elde edilen sonuçların genel olup olmadığını ve farklı örneklemlerde tutarlı olup olmadığını belirleyebilmek için daha fazla araştırmaya ihtiyaç bulunmaktadır. 


\section{SON NOTLAR}

${ }^{1}$ Bu makalenin özeti II. Uluslararası Beden Eğitimi ve Sporda Sosyal Alanlar Kongresi bildiri kitapçığında yer almıştır.

\section{KAYNAKLAR}

Altarawneh, I. ve Al-Kilani, M.H. (2010) "Human Resource Management and Turnover Intentions in the Jordanian Hotel Sector" Research and Practice in Human Resource Management, 18(1):46-59.

Al-Qutop, M.A.Y. ve Harrim, H. (2011) "Quality of Worklife Human Well-Being Linkage: Integrated Conceptual Framework" International Journal of Business and Management, 6(8):193-205.

Beh, L. ve Rose, R.C. (2007) "Linking QWL and Job Performance: Implications for Organizations" Performance Improvement, 46(6):30-35.

Chang, C.P. ve Chang, W.C. (2008) "Internal Marketing Practices and Employees' Turnover Intentions in Tourism and Leisure Hotels" The Journal of Human Resource and Adult Learning, 4(2):161-172.

Cherns, A. (1975) "Perspectives on the Quality of Working Life" Journal of Occupational Psychology, 48(3):155-167.

Davis, L. (1977) "Enhancing the Quality of Work Life: Developments in the United States of America" International Labor Review, 116(1):53-65.

Demir, M. (2011) "Relationships between Employees' Perceptions of Quality of Work Life, Intent to Remain with the Organization and Employee Absenteeism" Ege Academic Review, 11(3):453-464.

Demirbilek, S. ve Türkan, Ö.U. (2008) "Çalışma Yaşamı Kalitesinin Artırılmasında Personel Güçlendirmenin Rolü” Is, Guc, The Journal of Industrial Relations and Human Resources, 10(1):47-67.

Dess, G.G. ve Shaw, J.D. (2001) "Voluntary Turnover, Social Capital, and Organizational Performance" Academy Managemet Review, 26(3):446-456.

Edvardsson, B. ve Gustavsson, B. (2003) "Quality in the Work Environment: A Prerequisite for Success in New Service Development" Managing Service Quality, 13(2):148-163.

Erdem, M. (2010) "Quality of Work Life and its Relation to Organizational Commitment According to Teachers in Secondary Schools" Educational Administration:Theory and Practice, 16(4):511-536.
Gormley, D.K. ve Kennerly, S. (2010) "Influence of Work Role and Perceptions of Climate on Faculty Organizational Commitment" Journal of Professional Nursing, 26(2):108-115.

Havlovic, S.J. (1991) "Quality of Work Life and Human Resource Outcomes" Industrial Relations, 30(3):469-479.

Huang, T.C., Lawyer, J. ve Lei, C.Y. (2007) "The Effects of Quality of Work Life on Commitment and Turnover Intention" Social Behavior and Personality, 35(6):735-750.

Kornbluh, H. (1984) "Work Place Democracy and Quality of Work Life: Problems and Prospects" Annals of the American Academy of Political and Social Science, 1(473):88-95.

Korunka, C., Hoonakker, P. ve Carayon, P. (2008) "Quality of Working Life and Turnover Intention in Information Technology Work" Human Factors and Ergonomics in Manufacturing, 18(4):409-423.

Lambert, E. ve Paoline, E.A. (2010) "Take This Job and Shove it: An Exploratory Study of Turnover Intent among Jail Staff' Journal of Criminal Justice, 38(2):139-148.

Landau, J. ve Hammer, T.H. (1986) "Clerical Employees' Perceptions of Intraorganizational Career Opportunities" Academy of Management Journal, 29(2):385-404.

Lau, R.S.M. ve May, B.E. (1998) "A Win-win Paradigm for Quality of Work Life and Business Performance" Human Resource Development Quarterly, 9(3):211-226.

Lau, R.S.M. (2000) "Quality of Work Life and Performance-An Investigation of Two Key Elements in the Service Profit Chain Model" International Journal of Service Industry Management, 11(5):422-437.

Liu, B., Liu, J. ve Hu, J. (2010) “Person-Organization Fit, Job Satisfaction, and Turnover Intention: An Empirical Study in the Chinese Public Sector" Social Behavior and Personality, 38(5):615-626.

Moen P. (1999) "Effective Work/Lifes: Working Couples, Work Conditions, Gender, and Life Quality" Social Problems, 47(3):291-326. 
Nadler, D. ve Lawler, E. (1983) "Quality of Work Life: Perspectives and Directions" Organizational Dynamics, 11:22-36.

Nayeri, N.D., Salehi, T. ve Noghabi, A.A.A. (2011) "Quality of Work Life and Productivity among Iranian Nurses" Contemporary Nurse, 39(1):106-118.

Nazim A. (2008) "Factors Affecting Overall Job Satisfaction and Turnover Intention" Journal of Managerial Sciences, 2(2):239-252.

Sabarirajan, A. ve Geethanjali, N. (2011) "A Study on Quality of Work Life and Organizational Performance among the Employees of Public and Private Banks in Dindigul" International Journal of Economics and Research, 2(6):38-45.

Şahin, F. (2011) "The Effect of Gender on the Relationship between Leader-Member Exchange and Intention to Quit" Ege Academic Review, 11(2): 277-288.

Schermerhorn, J.R., Hunt, J.G. ve Osborn, R.N. (1994) Managing Organizational Behavior, 5th Edition, New York, John Wiley and Sons.

Smith, C., Daskalaki, M., Elger, T. ve Brown, D. (2004) "Labour Turnover and Management Retention Strategies in New Manufacturing Plants" International Journal of Human Resource Management, 15(2):371-396.

Staw, B.M. (1980) "The Consequences of Turnover" Journal of Occupational Behaviour, 1(4):253-273.

Turunç, O., Tabak, A., Şeşen, H. ve Türkyılmaz, A. (2010) "The Effect of Work Life Quality on Procedural Justice, Job Satisfaction, Job Stress and Intention to Quit" Is, Guc, The Journal of Industrial Relations and Human Resources, 12(3):77-96.

Wallace, C., Pichler, F. ve Hayes, B.C. (2007) "First European Quality of Life Survey: Quality of Work and Life Satisfaction" European Foundation for The Improvement of Living and Working Conditions, 1-68.
Wasmuth, W.J. ve Dawis, S.W. (1983) "Managing Employee Turnover" Cornell Hotel and Restaurant Administration Quarterly, 24(1):15-22.

Wasmuth, W.J. ve Dawis, S.W. (1993) "Managing Employee Turnover: Why Employees Leave" Cornell Hotel and Restaurant Administration Quarterly, 24(2):1118.

Watrous, K.M., Huffman, A.H. ve Pritchard, R.D. (2006) "When Coworkers and Managers Quit: The Effects of Turnover and Shared Values on Performance" Journal of Business and Psychology, 21(1):103-126.

Wells, J.E. ve Peachey, J.W. (2011) “Turnover Intentions: Do Leadership Behaviors and Satisfaction with the Leader Matter?" Team Performance Management, 17(1/2):23-40

Xhallorari, L. (2011) "Constructs of Quality of Work Life: A Perspective of Mental Health Professionals” Social Studies, 2(5):123-130.

Yıldız, S.M. (2011) "İçsel Pazarlama, İş Tatmini ve Örgütsel Bağlılık İlişkisi: Spor Okulu Antrenörleri Üzerine Bir İnceleme” Selçuk Üniversitesi Beden Eğitimi ve Spor Bilim Dergisi, 13(2):216-225.

Yin-Fah, B.C., Foon, Y.S., Chee-Leong, L. ve Osman, S. (2010) "An Exploratory Study on Turnover Intention among Private Sector Employees" International Journal of Business and Management, 5(8):57-64.

Zin, R.M. (2004) "Perception of Professional Engineers Toward Quality of Worklife and Organizational Commitment: A Case Study" Gadjah Mada Inlentalional Journal of Business, 6(3):323-334.

High Cost of Employee Turnover, http://www. wf1broward.com/upload/2261/High_cost_of_ Employee_Turnover-jm514.pdf, (07.05.2012). 